\title{
INFLUENCE OF GEOLOGY ON TUNNEL BORING MACHINE PERFORMANCE - A REVIEW
}

\author{
P.K. Pandey¹, A.K. Raina1", S. Deshmukh¹, R. Trivedi', R. Vajre', V.M.S.R. Murthy² \\ ${ }^{1}$ CSIR-Central Institute of Mining and Fuel Research, Nagpur Research Centre, Nagpur, India \\ 2Department of Mining Engineering, IIT(ISM), Dhanbad, India
}

(Received: November 21, 2019; Accepted: May 8, 2020)

\begin{abstract}
Tunnel boring machines are used for excavating a variety of soils and rocks for circular cross-section tunnels. Several published studies examined the role of rockmass in determining the cutting and advance rate of tunnel boring machines. $A$ comprehensive review of literature was conducted to ascertain the influence of geological conditions on the performance of tunnel boring machines and revealed that different rock characteristics were used to define the tunnel boring machine performance. The progress of the tunnel boring machine was ascribed to the inherent properties of the rockmass, intact rock properties, and surrounding geological conditions. Several authors found that extreme geological conditions strongly influence the advance of the machine. The review revealed that joint spacing, angle between plane of weakness and tunnel axis, rock quality designation, and number of joint sets were the most important variables that influenced the advance rates of the tunnel boring machine. At least 12 intact rock variables were used to define tunnel boring machine performance with one to seven such variables used in combination. The compressive strength, tensile strength, and brittleness index emerged as most crucial intact properties. Rockmass classifications or indices of tunnel boring machine performance were used by different authors to predict their performance and even to define their selection methodology. Use of dynamic properties of rock/rockmass was identified as a grey area for future research by scientists.
\end{abstract}

Key words: Tunnel boring machine performance; Rock mass properties; Intact rock properties; Special conditions; Review.

\section{Introduction}

Rapid growth of the world's population increases the demand for energy and that, in turn, accelerates requirements in dependent sectors for tunnelling. The case of the increase in population and a corresponding increase in energy demand in India is presented in Figure 1. The increase in demand for energy, as well as the demand for tunnelling for hydroelectric power generation, is reflected in the annual energy demand in the country, as shown in Fig. 2 [1, 2], consequent electricity production, both in hydropower and gross energy generation.

India is mainly dependent on fossil fuels for electricity generation. Hydroelectric power generation is an alternative competitive renewable source of energy. The shift in the strategy for cleaner production is evidenced by the growth in the contribution of hydroelectric power to total electricity generation from 2012-13 to 2016-17 in India (Figure 2). The growth in the hydropower sector is a clear indication of the increasing demand for tunnelling.

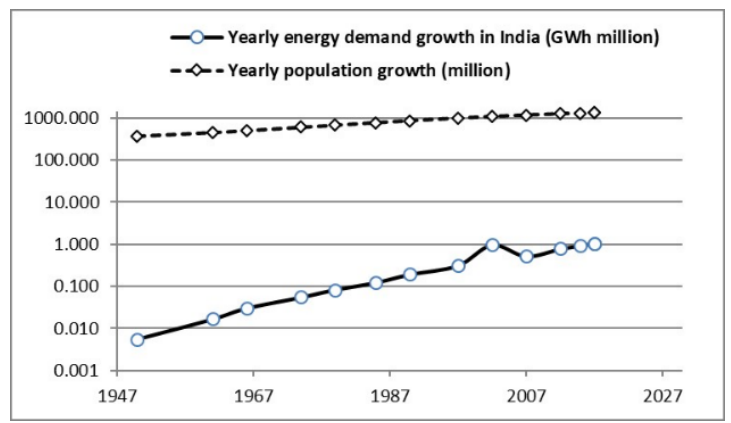

Figure 1 Population growth and energy demand in India [drawn after 3 and 4]

Besides hydroelectric projects, tunnel boring machines are used for other purposes. Tunnels and underground spaces are considered better alternatives for major structures since the available surface land is

\#Corresponding author: rainaji@cimfr.nic.in

doi: 10.5937/JMMA2001001P 
already constrained. Rapid urbanization has also increased the need for tunnelling in various sectors in order to fulfil the demand for power, transport, sewage, and irrigation.

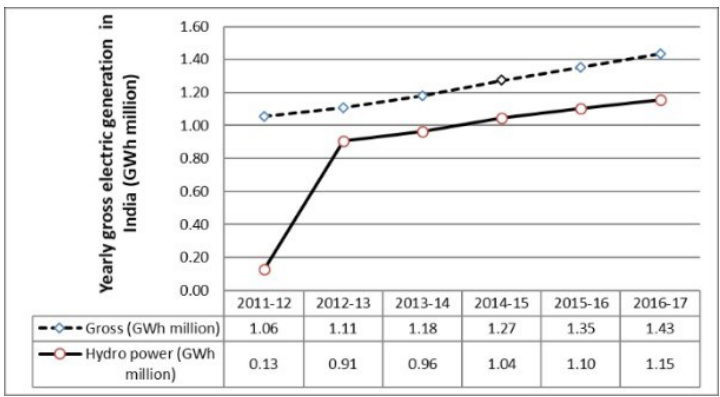

Figure 2 Contribution of hydroelectric power to gross power generation in India [drawn after 3]

Figure 3 shows the sector-wise share of tunnelling. Major tunnelling is currently being deployed in hydroelectric power projects with a share of $49 \%$ of total tunnelling. Tunnelling for irrigation projects assumes second rank (20\%). All other tunnelling activities constitute the remaining $31 \%$ of the total [5].

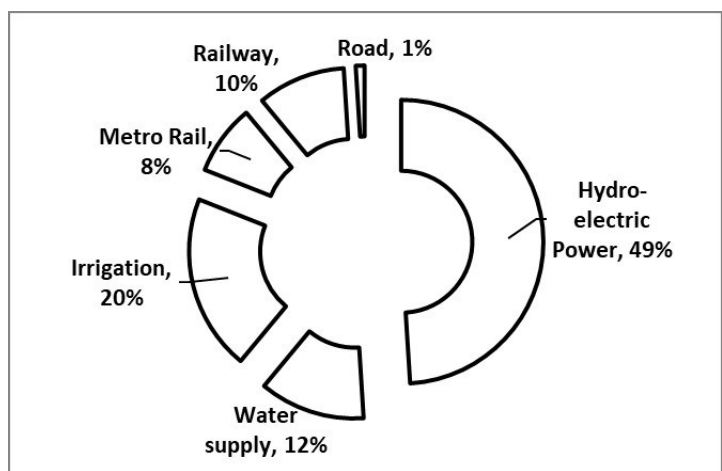

Figure 3 Application of tunnelling for different sectors in India [drawn after 5]

Methods of excavation, tunnelling economics, stability, and safety are major concerns in tunnelling. Besides mechanical devices such as tunnel boring machines and road headers, methods such as drilling and blasting can also be used for creating underground tunnels. As can be seen from Figure 4, about $69 \%$ of overall tunnelling is done with drill and blast. However, this method has disadvantages, such as damage to the parent rock and nuisance of noise and vibrations for local populations. Consequently, there are related environmental and legal issues to be overcome.
Although TBM excavation is sensitive to geological formations, it is considered the safest form of tunnelling. Tunnelling with a TBM is also a cost-effective alternative to the drill and blast method. The tunnel boring machine (TBM) has thus found its place as a major method of tunnelling, as is evident from Figure 4.

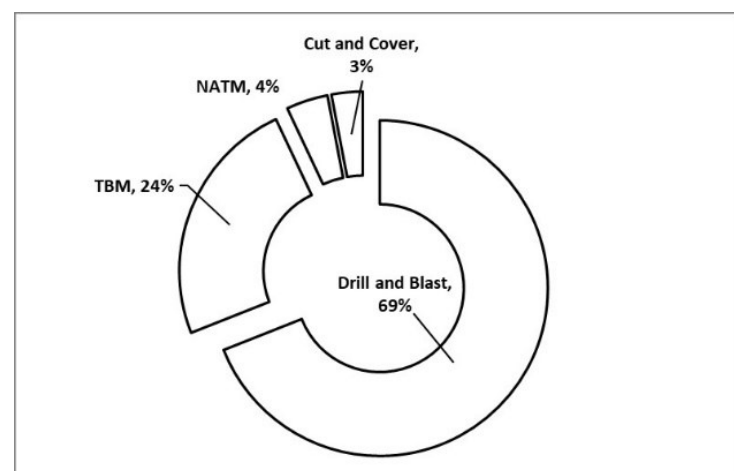

Figure 4 Percentage of different tunnelling techniques [drawn after 5]

TBMs can be used on both soft and hard rock types and can cut rock in varied geological conditions. These advantages make the TBM attractive and, at times, make it the first choice for tunnelling projects especially in urban environments. Advance rates, reliability, low strata disturbance, safety and low labour deployment and simultaneous support erection are some of the advantages of a TBM. Moreover, the TBM produces uniform fragment size and that is an advantage in the removal and transport of mucking. A comparison of the drill and blast method and tunnelling with TBMs is given in Table 1.

Despite being a mechanical method of excavation, the TBM is simple to operate. TBMs do not disturb the surrounding rock mass as they produce minimal vibrations. Since the surrounding rock mass is minimally disturbed during excavation, support requirements are low and safety is enhanced. This is a major advantage of TBMs as roof stability is very important in underground excavations and tunnelling. Moreover, the final excavation surface is quite smooth and energy to meet ventilation requirements reduces considerably [6]. In addition, the overbreak and support costs thereof are reduced.

An added advantage of the TBM is that it can drive exactly on a planned path of excavation by means of a guide system. TBMs may also be used for microtunnelling [7] with diameters of less than one meter as 
well as in roadway and railway tunnelling with diameters of more than $15 \mathrm{~m}$. They can also be used in trenchless construction. These are probably why the TBM is one of the most suitable options for tunnelling.

Table 1 Comparison of TBM with drilling and blasting methods for underground tunnelling

\begin{tabular}{|c|c|c|c|}
\hline $\begin{array}{l}\text { Sl. } \\
\text { No. }\end{array}$ & Issues & TBM & $\begin{array}{c}\text { Drilling and } \\
\text { Blasting }\end{array}$ \\
\hline 1 & $\begin{array}{l}\text { Ground } \\
\text { vibration }\end{array}$ & $\begin{array}{l}\text { Low but } \\
\text { continuous }\end{array}$ & $\begin{array}{l}\text { High but } \\
\text { transient }\end{array}$ \\
\hline 2 & Noise & $\begin{array}{l}\text { Low but } \\
\text { continuous }\end{array}$ & $\begin{array}{l}\text { High but } \\
\text { transient }\end{array}$ \\
\hline 3 & Accidents & Minimum & High \\
\hline 4 & Tunnel profile & Even & Uneven \\
\hline 5 & $\begin{array}{l}\text { Ventilation } \\
\text { requirement }\end{array}$ & Low & High \\
\hline 6 & $\begin{array}{l}\text { Rock mass } \\
\text { damage }\end{array}$ & Minimal & Relatively high \\
\hline 7 & Fragmentation & Uniform & Uneven \\
\hline 8 & Tunnelling rate & $\begin{array}{c}\text { Relatively } \\
\text { high }\end{array}$ & Relatively low \\
\hline 9 & Operations & Continuous & Cyclic \\
\hline 10 & Constraints & $\begin{array}{c}\text { Major issues if } \\
\text { stuck }\end{array}$ & $\begin{array}{c}\text { Fumes, } \\
\text { accidents }\end{array}$ \\
\hline
\end{tabular}

TBMs are expensive. It is difficult to transport the machine to tunnelling sites. It tunnels in a unidirectional manner and it is prone to getting stuck in adverse geological conditions. These disadvantages sometimes result in escalating tunnelling costs. However, the cost of tunnelling with a TBM goes down as the length of the tunnel increases [8].

The types of TBMs developed so far include open face, gripper, slurry, earth pressure balance, single and double shield, mixed shield, and convertible shield types [9]. The selection of a TBM depends on the geology of the excavation. Consequently, TBMs are assembled in line with lithology and rock mass conditions. So, an understanding of rock mass and intact rock properties for the deployment of a TBM assume importance. A significant part of the published literature addresses such topics. This analysis in the basis of compilation and critical review of the existing literature. Such findings can help in holistic understanding of role of geology in TBM performance also lay a foundation for future research.

\section{Intact rock properties and TBM performance}

Intact rock contains neither joints nor cracks. The breakage in case of massive or intact rock is practically defined by its internal granular structure. Intact rock properties can be determined in the laboratory with relative ease and then used for multiple purposes including working out TBM penetration rates.

Uniaxial compressive strength (UCS) and in situ stress conditions also influence geomechanical and geotechnical parameters which control the rate of tunnelling [10]. The UCS is considered to be the most influencing variable in TBM penetration and cutter life is strongly affected by joint frequency. However, not only uniaxial compressive strength (UCS) and Brazilian tensile strength (BTS), but also the spacing and orientation of fracture and the brittleness of rock can be more important than intact rock strength in determining TBM performance rate in hard rock conditions [11].

Abrasivity as modelled (abrasivity index) by [12] is an important parameter since it determines cutter wear. The strength of the rock, the abrasivity of the rock and the degree of jointing determine the cutter cost and penetration rate of a TBM [13; Equations 1 and 2].

$C_{c}=\frac{d_{T}}{P_{c}}+\frac{\sigma_{c} \times C_{l}}{J_{f}}$

$R_{p}=\frac{P_{c}}{d_{T}^{2} \times S_{c} \times \alpha_{c}}+\frac{J_{f}}{\sigma_{c}}$

where, $C_{c}$ is cutter cost per linear meter of tunnel, $d_{T}$ is diameter of tunnel, $P_{c}$ is cutter thrust, $\sigma_{c}$ is compressive strength of intact rock, $C_{l}$ is abrasivity index, $J_{f}$ is intensity of jointing, $\alpha_{c}$ is cutter edge angle, and $R_{p}$ is penetration rate.

The influence of intact rock properties on TBM performance has been modelled by different authors (Table 2).

Though different authors use one to six variables in various combinations (Table 2), a total of 12 intact rock properties have been applied to characterize TBM performance. It is also observed that uniaxial compressive strength (UCS), Brazilian tensile strength (BTS), brittleness index (BI), abrasivity, drilling rate index (DRI), and cohesion of joint plane emerge as major contributing factors in TBM performance (Figure 5). Though empirical and multivariate analysis were the 
major methods deployed for such an analysis, more

vector machines have also been used to predict recently, artificial intelligence methods like support

performance [43].

Table 2 Review of intact rock properties affecting TBM performance

\begin{tabular}{|c|c|c|c|c|c|c|c|c|c|c|c|c|c|c|}
\hline \multirow[t]{2}{*}{ Sl. No. } & \multirow[t]{2}{*}{ Author(s) } & \multicolumn{12}{|c|}{ Reported intact rock properties influencing TBM performance } & \multirow[t]{2}{*}{ Total } \\
\hline & & 1 & 2 & 3 & 4 & 5 & 6 & 7 & 8 & 9 & 10 & 11 & 12 & \\
\hline 1 & Graham, 1976 [14] & $\sqrt{ }$ & & & & & & & & & & & & 1 \\
\hline 2 & Farmer and Glossop, 1980 [15] & & $\sqrt{ }$ & & & & & & & & & & & 1 \\
\hline 3 & Snowdown et al. 1983 [16] & $\sqrt{ }$ & $\sqrt{ }$ & & & & & & & & & $\sqrt{ }$ & & 3 \\
\hline 4 & Buchi 1984 [17] & $\sqrt{ }$ & $\sqrt{ }$ & & & & & & & & & & & 2 \\
\hline 5 & Morimoto and Hori 1986 [18] & & & & & & & & & & & & $\sqrt{ }$ & 1 \\
\hline 6 & Hughes 1986 [19] & $\sqrt{ }$ & & & & & & & & & & & & 1 \\
\hline 7 & Rostami and Ozdemir 1993 [20] & $\sqrt{ }$ & $\sqrt{ }$ & & & & & & & & & & & 2 \\
\hline 8 & Nilsen 1993 [21] & & & $\sqrt{ }$ & $\sqrt{ }$ & & & & & & & & & 2 \\
\hline 9 & Rostami et al. 1996 [22] & $\sqrt{ }$ & $\sqrt{ }$ & $\sqrt{ }$ & $\sqrt{ }$ & $\sqrt{ }$ & & & & & & & & 5 \\
\hline 10 & Bruland 1998 [23] & $\sqrt{ }$ & & & & $\sqrt{ }$ & & & & & & & & 2 \\
\hline 11 & Barton 1999 [24] & & & & & & $\sqrt{ }$ & & & $\sqrt{ }$ & & & & 2 \\
\hline 12 & Boniface 2000 [25] & $\sqrt{ }$ & & & & $\sqrt{ }$ & & & & & $\sqrt{ }$ & $\sqrt{ }$ & & 4 \\
\hline 13 & Barton 2000 [26] & & & & & & $\sqrt{ }$ & & & $\sqrt{ }$ & & & & 2 \\
\hline 14 & Cigla 2001 [27] & $\sqrt{ }$ & $\sqrt{ }$ & $\sqrt{ }$ & $\sqrt{ }$ & & & & & & & & & 4 \\
\hline 15 & Kahraman 2002 [28] & & & $\sqrt{ }$ & & & & $\sqrt{ }$ & & & & & & 2 \\
\hline 16 & Sapigni 2002 [29] & $\sqrt{ }$ & $\sqrt{ }$ & & $\sqrt{ }$ & $\sqrt{ }$ & $\sqrt{ }$ & & & & $\sqrt{ }$ & & & 6 \\
\hline 17 & $\begin{array}{l}\text { Benerdos and Kaliampakos } \\
2004[30]\end{array}$ & $\sqrt{ }$ & & & & & & & & & & & & 1 \\
\hline 18 & Bilgin et al. 2005 [31] & $\sqrt{ }$ & $\sqrt{ }$ & & & & & & & & & & & 2 \\
\hline 19 & Yagiz 2006 [11] & $\sqrt{ }$ & $\sqrt{ }$ & $\sqrt{ }$ & & & & & & & & & & 3 \\
\hline 20 & Gong et al. 2006 [32] & & $\sqrt{ }$ & & & & & & $\sqrt{ }$ & & & & & 2 \\
\hline 21 & Von Preinl et al. 2006 [33] & $\sqrt{ }$ & & & $\sqrt{ }$ & & & & & & & & & 2 \\
\hline 22 & Yagiz et al. 2009 [34] & $\sqrt{ }$ & $\sqrt{ }$ & $\sqrt{ }$ & & & & & & & & & & 4 \\
\hline 23 & Hassanpour et al. 2010 [35] & $\sqrt{ }$ & & & & & & & & & & & & 1 \\
\hline 24 & Gong and Zhao 2009 [36] & $\sqrt{ }$ & & $\sqrt{ }$ & & & & & & & & & & 2 \\
\hline 25 & $\begin{array}{l}\text { Gholamnejed and Tayarani } \\
2010[37]\end{array}$ & $\sqrt{ }$ & & & & & & & & & & & & 2 \\
\hline 26 & Hamidi et al. 2010 [38] & $\sqrt{ }$ & & & & & & & & & & & & 1 \\
\hline 27 & Benato and Oreste 2015 [39] & $\sqrt{ }$ & & & & & & & & & & & & 1 \\
\hline 28 & Salimi et al. 2016 [40] & $\sqrt{ }$ & $\sqrt{ }$ & & & & & & & & & & & 2 \\
\hline 29 & Liu et al. 2017 [41] & $\sqrt{ }$ & & & & & & $\sqrt{ }$ & & & & & $\sqrt{ }$ & 3 \\
\hline 30 & Namli and Bilgin 2017 [42] & $\sqrt{ }$ & & & & & & & $\sqrt{ }$ & & & & & 2 \\
\hline & Total & 23 & 12 & 7 & 5 & 4 & 3 & 2 & 2 & 2 & 2 & 2 & 2 & \\
\hline
\end{tabular}




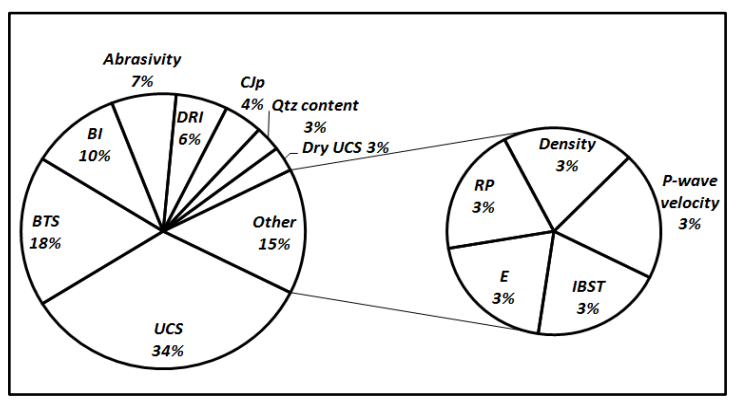

Figure 5 Importance of various intact rock properties in relation to TBM performance

\section{Geology, structures and TBM performance}

Though TBMs can achieve an excavation rate of $1000 \mathrm{~m} / \mathrm{month}$, in adverse geological conditions, the rate of excavation may be less than $50 \mathrm{~m} /$ month $[44,45]$ or even a few meters in extreme rock mass conditions [24]. In special cases, such as in very hard rock formations, highly fractured and jointed rock mass, large groundwater inflow and high in situ stress conditions, using a TBM can lead to excavation stoppage.

If the rock mass bears a high frequency of fracture planes and/or tectonic disturbances, the inherent strength of the rock mass is reduced, thus decreasing wall rock stability. This type of situation reduces the progress of TBM tunnelling, as support systems have to be installed immediately for safe and stable tunnelling $[46,47]$. Important publications dealing with the influence of rock mass on TBM performance were therefore compiled and analysed to identify variables impacting TBM progress (Table 3).

Table 3 Review of rock mass properties of TBM performance module

\begin{tabular}{|c|c|c|c|c|c|c|c|c|c|c|c|c|c|c|c|}
\hline \multirow[t]{2}{*}{ Sl. No. } & \multirow[t]{2}{*}{ Author(s) } & \multicolumn{13}{|c|}{ Reported rock mass properties influencing TBM performance } & \multirow[t]{2}{*}{ Total } \\
\hline & & 1 & 2 & 3 & 4 & 5 & 6 & 7 & 8 & 9 & 10 & 11 & 12 & 13 & \\
\hline 1 & Buchi 1984 [17] & $\sqrt{ }$ & & & & & & & & & & & & & 1 \\
\hline 2 & Bruland 1998 [23] & $\sqrt{ }$ & & & $\sqrt{ }$ & & & & & $\sqrt{ }$ & & & & & 3 \\
\hline 3 & Barton 1999 [24] & & & & $\sqrt{ }$ & $\sqrt{ }$ & & & & $\sqrt{ }$ & $\sqrt{ }$ & $\sqrt{ }$ & $\sqrt{ }$ & $\sqrt{ }$ & 7 \\
\hline 4 & Barton 2000 [26] & & & & $\sqrt{ }$ & $\sqrt{ }$ & & & & $\sqrt{ }$ & $\sqrt{ }$ & $\sqrt{ }$ & $\sqrt{ }$ & $\sqrt{ }$ & 7 \\
\hline 5 & Cigla 2001 [27] & $\sqrt{ }$ & $\sqrt{ }$ & & & $\sqrt{ }$ & & & & & & & & & 3 \\
\hline 6 & $\begin{array}{l}\text { Benerdos and Kaliampakos } 2004 \\
\text { [30] }\end{array}$ & & & $\sqrt{ }$ & & & & & $\sqrt{ }$ & & & & & & 2 \\
\hline 7 & Bilgin et al. 2005 [31] & $\sqrt{ }$ & & $\sqrt{ }$ & & & & & & & & & & & 2 \\
\hline 8 & Gong et al. 2006 [32] & $\sqrt{ }$ & & & & & & & & & & & & & 1 \\
\hline 9 & Yagiz 2006 [11] & $\sqrt{ }$ & $\sqrt{ }$ & & & & & & & & & & & & 2 \\
\hline 10 & Von Preinl et al. 2006 [33] & & & & $\sqrt{ }$ & $\sqrt{ }$ & & & & & & & & & 2 \\
\hline 11 & Yagiz et al. 2009 [34] & & $\sqrt{ }$ & & & & & & & & & & & & 1 \\
\hline 12 & Hassanpour et al. 2010 [35] & $\sqrt{ }$ & $\sqrt{ }$ & $\sqrt{ }$ & & & & & & & & & & & 3 \\
\hline 13 & Gong and Zhao 2009 [36] & & $\sqrt{ }$ & & $\sqrt{ }$ & & & & & & & & & & 2 \\
\hline 14 & Hamidi et al., 2010 [38] & $\sqrt{ }$ & $\sqrt{ }$ & $\sqrt{ }$ & & & & & & & & & & & 3 \\
\hline 15 & Gholamnejed and Tayarani 2010 [37] & & & $\sqrt{ }$ & & & & & & & & & & & 1 \\
\hline 16 & Benato and Oreste 2015 [39] & & & & & & $\sqrt{ }$ & $\sqrt{ }$ & & & & & & & 2 \\
\hline 17 & Salimi et al. 2016 [40] & $\sqrt{ }$ & $\sqrt{ }$ & $\sqrt{ }$ & & & $\sqrt{ }$ & $\sqrt{ }$ & $\sqrt{ }$ & & & & & & 6 \\
\hline 18 & Salimi et al. 2017 [48] & & $\sqrt{ }$ & $\sqrt{ }$ & & & $\sqrt{ }$ & $\sqrt{ }$ & $\sqrt{ }$ & & & & & & 5 \\
\hline 19 & Liu et al. 2017 [41] & & $\sqrt{ }$ & & & $\sqrt{ }$ & $\sqrt{ }$ & $\sqrt{ }$ & $\sqrt{ }$ & & & & & & 5 \\
\hline 20 & Namli and Bilgin 2017 [42] & & & $\sqrt{ }$ & & & $\sqrt{ }$ & $\sqrt{ }$ & & & & & & & 3 \\
\hline & Total & 9 & 9 & 8 & 5 & 5 & 5 & 5 & 4 & 3 & 2 & 2 & 2 & 2 & \\
\hline
\end{tabular}

1 = Joint spacing; 2 = Alpha (Angle between plane of weakness and tunnel axis); $3=R Q D$ (Rock Quality Designation); 4 = Jn (No. of joint sets); 5 = Jw (Joint water condition); 6 = GSI (Geological Strength Index); 7 = Q-Index; 8 = RMR (Rock Mass Rating); $9=$ Mohs' hardness; $10=R Q D 0$ (Conventional $R Q D$ interpreted in the tunnelling degree); $11=$ Rock mass strength; 12 = Porosity; $13=\mathrm{Jr}$ (Roughness of the most unfavourable joint or discontinuity) 
Various authors have applied one to seven variables in combinations to characterize TBM performance based on rock mass characteristics, thus identifying a total of 13 rock mass properties (Table 3 ). Joint spacing, angle between plane of weakness and tunnel axis, Rock Quality Designation (RQD), Rock mass strength (RMS), number of joint sets, joint water condition, Geological Strength Index (GSI), Q-index, and Rock Mass Rating (RMR) emerge as major factors that can be used to model TBM performance (Figure 6). The properties that have been used range from individual to groups (as classifications).

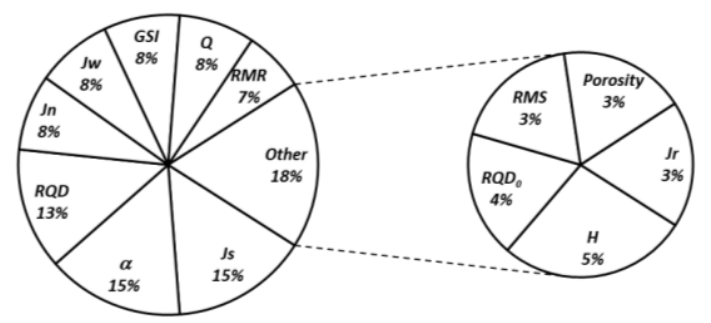

Figure 6 Importance of various rock mass properties in relation to TBM performance

It is also clear from Table 3 that initial attempts to correlate TBM performance were driven by independent rockmass variables. However, later attempts have focused on classifications like GSI, QTBM, and RMR to define TBM performance as these can accommodate several variables.

\subsection{Influence of Joint Sets and Joint Spacing}

Joint spacing appears to have a major influence on the normal force on TBM cutters. When schistosity, joints, fractures, folds, faults and shear-zones, and groundwater inflow do not manifest in rock mass, the rock may be intact or massive. If the rock mass is too fractured and jointed, it can reduce tunnelling rate and increase the risk of roof collapse. This would call for roof supports, such as ring beams, rock/roof bolts, shotcrete, steel straps, ring steel, wire mesh, and concrete segments [49]. When there is less joint spacing, the normal force for the jointed rock mass is much lower than that of the intact rock mass. In case of rock mass with $400 \mathrm{~mm}$ of joint spacing, the normal force dramatically decreases and the cutting surface appears $280 \mathrm{~mm}$ away from the joint plane [50].

The effect of joint spacing is minimal when joint spacing is around $500 \mathrm{~mm}$ and the effect is highly significant if joint spacing is around $10 \mathrm{~mm}$. When joint spacing is less than $200 \mathrm{~mm}$, chipping stress increases rapidly and, when it is $>200 \mathrm{~mm}$, chipping stress increases mildly [32]. With decrease in joint spacing, the TBM penetration rate increases distinctly [23]. If joint spacing is $20-100 \mathrm{~mm}$ and the angle of attack varies from $30^{\circ}$ to $90^{\circ}$ with tunnel axis, then less force is required for maximum penetration [51]. This way, the strata into which the tunnel is driven and the angle and orientation of the joint of the strata play an important role in defining the excavation rate of TBMs.

$\mathrm{RQD}$ also finds a place in most used factor, probably because it has a relationship with joint spacing, [52] established correlation between field penetration index (FPI), rock mass cuttability index (RMCl), and RQD (Eq. 1 and 2).

$$
F P I=10.52 e^{0.011 R M C l}
$$

$R M C l=\frac{\sigma_{c}}{100} R Q D^{\frac{2}{3}}$

where $F P I$ is field penetration index, $R M C l$ is rock mass cuttability index, and $R Q D$ is rock quality designation.

Table 4 Review of some geological conditions that impact TBM efficiency

\begin{tabular}{|c|c|c|}
\hline Author & Geological condition & Effect on TBM efficiency \\
\hline Yin et al. 2016 [50] & Joint spacing and fracture & Cutting rate increases with less joint spacing and vice-versa \\
\hline Paltrinieri 2016 [54] & $\begin{array}{l}\text { Fault and shear zone, high in situ stress } \\
\text { and groundwater inflow }\end{array}$ & Each reduces TBM performance independently \\
\hline Rostami 1996 [22] & Brittleness of rock & $\begin{array}{l}\text { Low - Increases TBM penetration } \\
\text { High - Decreases TBM penetration }\end{array}$ \\
\hline Howarth1981 [51] & $\begin{array}{l}\text { Alpha (Angle between plane of } \\
\text { weakness and tunnel axis) }\end{array}$ & $\begin{array}{l}\text { When angle of attack varies from } 30^{\circ} \text { to } 90^{\circ} \text {, less force is } \\
\text { required for maximum penetration depth }\end{array}$ \\
\hline Bilgin et al. 2005 [31] & $\begin{array}{l}\text { Uniaxial Compressive Strength, } \\
\text { Brazilian Tensile Strength }\end{array}$ & $\begin{array}{l}\text { Low - increases TBM cutting rate } \\
\text { High - decreases TBM cutting rate }\end{array}$ \\
\hline Stack 1995 [49] & $\begin{array}{l}\text { If rock mass is too jointed, fractured, } \\
\text { folded, faulted and squished }\end{array}$ & Reduce the advance rate as roof support is required \\
\hline
\end{tabular}


The influence of various geological variables impacting TBM performance, as reported by different authors, is summarized in Table 4 . It is obvious that in soft rocks the penetration rates can be quite high but the support erection consumes significant time, thus hampering the advance rate. However, in the case of very hard rocks, the penetration rates are quite low, whereas the time and effort required to erect support structures are quite low [53].

\section{Influence of in-situ stress and fault zones}

Some major problems occur during tunnelling at fault-zones such as high ground pressure and subsequent loads on TBMs. In situ stresses such as degree of fracturing, weathering, influence of water, and depth of tunnel affect TBM performance during tunnelling in fault zone conditions (Table 5). Due to high and sudden inflows of groundwater, jamming of TBMs has been reported [55]. Tunnelling under fault-zone, heterogeneous structural disturbance and underground water inflow conditions are always dangerous and can lead to accidents and collapses [54]. Such conditions and extreme water inflows have even resulted in the abandoning of the TBM [56]. Between relatively weak and hard rock in a fault zone, the possibility of breaking more of the tunnel wall boundary increases when stress is homogeneous over the zone. In areas of fault-zones and where rock overburden is low, the use of ribs of reinforced shotcrete has normally been sufficient [57]. High vertical stresses due to large overburden can lead to major displacements during the course of tunnelling and may demand stiff supports. Such instances result in cost overrun and extended time for the completion of such projects.

Table 5 Various mining conditions involved in tunnel construction and their influence on progress

\begin{tabular}{|c|c|c|c|c|}
\hline $\begin{array}{l}\text { Sl. } \\
\text { No. }\end{array}$ & Condition & Sub-condition & $\begin{array}{l}\text { Impact on tunnel } \\
\text { progress }\end{array}$ & References \\
\hline \multirow[t]{4}{*}{1} & Rock mass condition & Hard rock massive & High - disadvantage & Bruland (1998) [23] \\
\hline & & Hard rock fractured & Less - advantage & \\
\hline & & Soft rock with high/ & High - disadvantage & Barton (1999) [24] \\
\hline & & Less fractures & Less - advantage & \\
\hline \multirow[t]{2}{*}{2} & Ground water condition & High water pressure & Disadvantage & Paltrinieri et al. (2016) [54] \\
\hline & & Less/no water pressure & Advantage & Paltrinieri et al. (2016) [54] \\
\hline \multirow[t]{2}{*}{3} & $\begin{array}{l}\text { Depth, shape, diameter } \\
\text { and appropriate risk }\end{array}$ & In situ stress condition & $\begin{array}{l}\text { High - disadvantage } \\
\text { Less - advantage }\end{array}$ & Swannell et al. (2016) [10] \\
\hline & management of tunnel & Roof stability problem & Disadvantage & Hoek et al. (1998) [58] \\
\hline
\end{tabular}

In addition, while developing a prediction model for the performance of the machine, [59] classified and determined clogging, swelling, abrasion, unstable tunnel face, and probable water flow as factors that impact the performance of a hard rock TBM deployed in soft rock conditions. Mostafaei et al. [60] determined the impact of variables such as moisture, lithology, grain size and foam of drilling on TBM performance. They highlighted the variations in TBM behaviour in different types of rock.

\subsection{Classification of fault-zones}

Paltrinieri et al. [54] dwelled on the degree of fracturing and weathering of the rock mass to define a fault-zone. They considered water inflows and depth of faulted or fractured zones as additional factors while developing a classification for such zones (Figure 7) and they concluded that these factors contribute to the reduction of TBM performance.

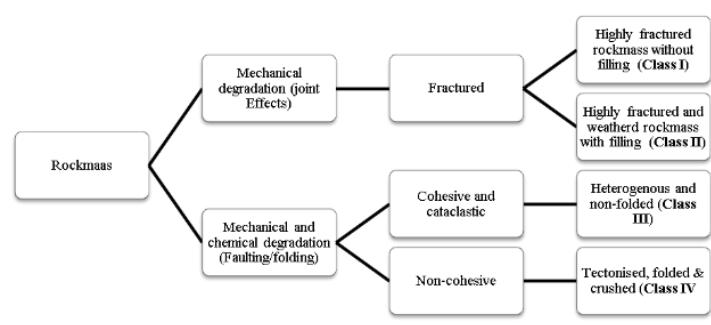

Figure 7 Fault-zone rock mass classification for underground tunnelling [54]

Mechanically degraded rocks with fractured nature were thus designated as Class I and II. Class III and IV fault-zones consist of low-strength rocks with high deformability index, as well as foliated/ overlaid/ sheared 
rock masses of non-blocky structures and a predominant set of discontinuities and slickenside surfaces. In such classes, deformation is controlled by shear strength and displacement along foliation planes [58].

\section{Rock mass classifications and modelling of penetration rate for TBM}

Rock mass classification is made to systematize onsite rock mass assessment and to categorize, on a common basis, analytical studies, measurements and field observations. The major objective of classification is to divide a particular rock mass formation into groups and to assess the parameters that influence rock mass behaviour during excavation. To model TBM progress, many authors have developed empirical relationships with different rock variables. A compilation of such relationships is summarised in Table 6 .

Table 6 Penetration rate of TBM as correlated with rock properties or classifications by various authors

\begin{tabular}{|c|c|c|}
\hline $\begin{array}{l}\text { Sl. } \\
\text { No. }\end{array}$ & Citations & Equation \\
\hline 1 & Cassinelli et al. 1982 [61] & $P R=-0.0059 \times R S R+1.59$ \\
\hline 2 & Nelson et al. 1983 [62] & $P R=10.45-1.19 \times H_{A}$ \\
\hline 3 & Boyd 1986 [63] & $P R=\frac{H P \times \eta}{c \Gamma \times 1}$ \\
\hline 4 & Innaurato et al. 1991 [64] & $P R=\sigma_{c}^{-0.437}-0.047 R S R+3.15$ \\
\hline 5 & Ramezanzadeh et al. 2008 [65] & CSM ROP 0.453 \\
\hline & & $\begin{aligned} P R & =\frac{\operatorname{Exp}(0.001 \times J S-0.002 \times P T I-0.687)}{C S M R O P^{0.407}} \\
P R & =\frac{C_{0}}{C<45}\end{aligned}$ \\
\hline 6 & Rostami et al. 1996 [22] & $\begin{array}{c}E x p(0.001 \times J S-0.002 \times \propto-0.002 \times P T I-0.632 \\
P R=R \times(1-\cos \phi)\end{array}$ \\
\hline 7 & Barton 2000 [26] & $\begin{array}{c}P R=5 \times Q_{T B M}^{-0.2} \\
Q_{T B M}=\frac{R Q D_{o}}{I_{n}} \times \frac{J_{r}}{J_{g}} \times \frac{J_{w}}{S R F} \frac{20^{9} \times S I G M A}{F^{10}} \frac{20}{C L I} \frac{q}{20} \frac{\sigma_{0}}{5}\end{array}$ \\
\hline 8 & Bruland1998 [23] & $I_{0}=\left(\frac{M_{e k v}}{M_{1}}\right)^{b}$ \\
\hline 9 & Ribacchi and Lembo-Fazio 2005 [66] & $S P=250 \times \sigma_{c m}^{-0.66}, \sigma_{c m}=\sigma_{c} \times e^{\left(\frac{R M R-100}{18}\right)}$ \\
\hline 10 & Mahdevari et al. 2014 [67] & $\begin{array}{c}A R A=0.56 \times(R M E-26)(\text { For } R M E>75) \\
\quad A R A=0.213 \times R M E(\text { For } R M R<75)\end{array}$ \\
\hline 11 & Bieniawski and Grandori 2007 [68] & $A R A=-0.422 \times R M E_{07}-11061$ \\
\hline 12 & Hassanpour et al. 2010 [35] & $\begin{array}{c}F P I=0.222 \times R M R+2.755 \\
F P I=9.273 e^{0.008 G S I}\end{array}$ \\
\hline 13 & Salimi et al. 2017 [48] & $\begin{aligned} F P I & =11.718 Q^{0.098} \\
P R=\frac{L_{b}}{t_{b}}, P & =\frac{R O P \times 1000}{R P M \times 60}, F P I=\frac{F_{n}}{P}\end{aligned}$ \\
\hline
\end{tabular}

Where $P R=$ penetration rate; $\sigma_{c}=$ uniaxial compressive strength of rock; $\sigma_{c m}=$ uniaxial compressive strength of rock mass; $A R A=$ average rate of advance; $F P I=$ field penetration index; $J_{n}, J_{r}, J_{a}, J_{w}$ and $S R F$ are original parameters of $Q$-system; $R Q D_{0}$ is orientated$R Q D$ in tunnelling direction; SIGMA = rock mass strength; $F=$ average cutter load; $C L I=$ cutter life index; $q=$ quartz content; $\sigma_{0}=$ average biaxial stress on tunnel face; $A d j R O P=$ adjusted rate of penetration; $C S M R O P=$ calculated rate of penetration; JS = Joint spacing; $\alpha=$ angle between tunnel axis and plane of weakness; $R O P=$ rate of penetration; $L_{b}=$ boring length; $t_{b}=$ boring time; $P=$ penetration per cutterhead revolution; $R P M=$ cutterhead rotational speed; $F_{n}=$ cutter load; $p=$ penetration rate; $H_{A}=$ Taber abrasion hardness; $\Phi=$ angle of shearing resistance; $H P=$ installed cutterhead power; $\eta=$ mechanical efficiency factor; $S E$ = specific energy; $A$ $=$ tunnel; $R S R=$ rock structure rating; $R=$ cutter radius; $G S I=$ geological strength index; $R M R=$ rock mass rating; $I_{0}=$ penetration per cutterhead revolution; $M_{\text {ekv }}=$ equivalent thrust; $M_{1}=$ critical thrust; $R M E=$ Rock mass excavatability; $P T I=$ punch test index

An examination of Tables 2 and 3 reveals that several properties have been used to model the penetration rate of TBMs (Table 6). While some researchers focus on rock mass characteristics, others have employed combinations of rock mass and intact properties. However, the degree and orientation of jointing, as well as the compressive strength and abrasivity of the intact rock have been used invariably to 
define penetration rates.

Two classification systems viz. Bieniawski's RMR and Barton's $Q$ have found a special place in such relationships and deserve mention. The penetration rate of TBMs was found to correlate well with modified RMR [66], but joint spacing also had a major influence. [26] Expanded his $Q$ system to QTBM that is a function of 20 variables and includes average cutter force, abrasive nature of the rock and stress levels in addition to normal $Q$. QTBM uses a relationship between penetration rate (PR) and QTBM to estimate TBM performance. If QTBM is greater than 1 , it represents bad rock mass condition and, due to this, would usually decrease the value of PR and, the lower the QTBM the higher the PR.

\section{Selection of TBM on the basis of different geological conditions}

TBM selection methodology is a formal process to gather information to make an informed decision to match a particular rock mass condition and lithology with an appropriate TBM. Modern TBMs [5] mainly consist of a rotating cutting wheel, i.e. a cutter head, a thrust system, and support mechanisms. However, as seen earlier, the type of machine that can be used for tunnelling is primarily dictated by the inherent properties of the geology including groundwater and other complex conditions as well as by the geomechanical properties of the rock. Hence, the selection of a TBM is a complex process. However, an attempt has been made here (Table 7) to present an overview of TBM deployment along with possible cutter types.

Despite the guidelines, a large tunnel project should start with a comprehensive investigation of geology and geological conditions. The project calls for a complete information database of the geology along the tunnel alignment, including minor details of sections and 3D models. It is important to have prior knowledge of the available TBMs and their specifications and features, to select the best TBM configuration for deployment.

Table 7 Use of TBMs and type of cutters in different type of ground conditions [after 69]

\begin{tabular}{|c|c|c|c|c|}
\hline Ground condition & Rock type & Lithology & Types of TBM used & Types of cutters used \\
\hline $\begin{array}{l}\text { Hard ground } \\
\text { condition }\end{array}$ & $\begin{array}{l}\text { Igneous and } \\
\text { metamorphic rock }\end{array}$ & $\begin{array}{l}\text { Granite, gabbro, } \\
\text { syenite andesite, } \\
\text { charnokite, gneiss, } \\
\text { peridotite, slate }\end{array}$ & $\begin{array}{l}\text { Shield (single/double) or } \\
\text { open type TBM }\end{array}$ & Disc cutter \\
\hline $\begin{array}{l}\text { Soft ground } \\
\text { condition }\end{array}$ & Sedimentary rock & $\begin{array}{l}\text { Clay, silt, sand and } \\
\text { gravels }\end{array}$ & $\begin{array}{l}\text { Earth pressure balance } \\
\text { (EPB), slurry shield (SS) } \\
\text { and open face type TBMs }\end{array}$ & $\begin{array}{l}\text { Carbide disc cutter } \\
\text { and hard rock disc } \\
\text { cutter }\end{array}$ \\
\hline $\begin{array}{l}\text { Soft ground with } \\
\text { ground water } \\
\text { pressure condition }\end{array}$ & $\begin{array}{l}\text { Sedimentary and } \\
\text { metamorphic } \\
\text { condition }\end{array}$ & Sandstone, shale & Slurry shield (SS)TBM & $\begin{array}{l}\text { Pressurized slurry } \\
\text { cutter }\end{array}$ \\
\hline $\begin{array}{l}\text { Urban and near } \\
\text { (shallow) surface } \\
\text { tunnelling } \\
\text { conditions }\end{array}$ & Mixed condition & $\begin{array}{l}\text { Clay, gravel, hard } \\
\text { rock }\end{array}$ & $\begin{array}{l}\text { Earth pressure balance } \\
\text { (EPB) and Slurry shield } \\
\text { (SS) TBMs }\end{array}$ & $\begin{array}{l}\text { Carbide disc cutter } \\
\text { and hard rock disc } \\
\text { cutter }\end{array}$ \\
\hline
\end{tabular}

While defining the type of wear, it has been observed [70] that the choice of ideal tools can be made with an understanding of the interaction between rock and cutters. Once deployed, the analysis of the performance continues and enormous data gets generated during the process. This leads to issues like big data handling and can be taken care of by methods like balanced iterative reducing and clustering using hierarchies [71].

Although significant research has been conducted on defining rock mass and intact properties that define the progress of a TBM, dynamic properties have scantly used to model the same. Such a study is necessitated by the fact that breakage is a dynamic process. Moreover, modern day geophysics allows us to determine the dynamic properties of in-situ rock and hence can present a viable alternative to eliminate human bias in empirical and laboratory studies of intact rocks.

\section{Conclusion}

The geology of an area plays a vital role in determining the performance of a tunnel boring 
machine. A comprehensive review of published literature indicated that the factors that influence the performance of a TBM can be categorised into nature of rock mass, intact rock properties, and special conditions such as the presence of faults, shear zone, or water content in the formation. Various models have been developed by different authors that have been summarised to predict TBM performance in the field. These models include rock mass or intact rock properties viz. joint spacing, angle between plane of weakness and tunnel axis, Rock Quality Designation, Rock Mass Rating, Geological Strength Index, Q-Index, Uniaxial Compressive Strength, Brazilian Tensile Strength, Brittleness Index/ plasticity of rock, abrasivity, and drillability of rock. Machine variables such as machine power, torque, RPM, cutter geometry, cutter spacing, tip width, and cutter type are dictated by rock type and lithology along with other laboratory properties of the rock. There are 13 rock mass properties and 12 intact rock properties or rock classification systems that have been applied to characterize TBM performance. Joint spacing, joint angle and RQD and UCS, BTS, and brittleness index emerge as major contributing factors in TBM performance. While intact rock properties affect cutting rate and define disc-cutter configurations, geological variables influence the overall productivity of the TBM. Tectonically disturbed formations are associated with overbreak and roof instability and reduce TBM cutting rate.

Systematic appraisal of the geology and geological conditions along the alignment of the proposed tunnel is indispensable. Every detail of the rock mass, geotechnical and intact rock properties determined in the laboratory can be useful at any stage of the project and should be acquired well before the onset of the excavation.

There is a significant gap in literature in terms of determining the dynamic properties of rock masses during tunnelling. Once the performance of the TBM is correlated with the dynamic properties, the relevant properties can be easily identified using geophysical surveys. This will avoid bias introduced due to empirical and lab-based assessment of rock properties.

\section{Acknowledgements}

Authors are thankful to Director CSIR-CIMFR for his permission to publish the review paper. Authors are also thankful to Central Power Research Institute and
Ministry of Power, Government of India for the research grant NPP/2016/HY/1/13042016.

\section{References}

[1] Growth of Electricity Sector in India from 19472017"[Accessed on 04-04-2019]

[2] Growth of Electricity Sector in India from 19472016" [Accessed on 05-04-2019]

[3] http://www.worldometers.info/worldpopulation/india-population/ [Accessed on 04-042019]

[4] https://en.wikipedia.org/wiki/Electricity_sector_in_In dia [Accessed on 04-04-2019]

[5] http://www.hccindia.com/whitepaper_pdf/2014/tunn eling-november-2014 [Accessed on 05-04-2019]

[6] Raina AK, Chakraborty AK, Ramulu M, Jethwa JL (2000) Rock mass damage from underground blasting, a literature review, and lab-and full-scale tests to estimate crack depth by ultrasonic method. Fragblast, 4(2):103-125

[7] Marinos V, Stoumpos G, Papouli D, Papazachos C (2019) Selection of TBM and geotechnical assessment of a microtunnel in a difficult geological environment: a case of a natural gas pipeline beneath an active landslide (Albania). Bulletin of Engineering Geology and the Environment, 78(3):1795-1813.

[8] https://en.wikipedia.org/wiki/Tunnel_boring_machin e [Accessed on 05-04-2019]

[9] Zhao J, Gong QM (2006) Rock mechanics and excavation by tunnel boring machine-issues and challenges. In Rock Mechanics in Underground Construction (With CD-ROM):83-96

[10] Swannell N, Palmer M, Barla G, Barla M (2016) Geotechnical risk management approach for TBM tunneling in squeezing ground conditions. Tunnelling and Underground Space Technology, 57:201-210.

[11] Yagiz S (2006) September. A model for the prediction of tunnel boring machine performance. In Proceedings of 10th IAEG Congress:1-10

[12] Schimazek J, Knatz H (1976) Die beurteilung der bearbeitbarkeit von gesteinendurchschneid-und rollenbohrwerkzeuge. Erzmetall, 29(3):113-119

[13] Robbins RJ (1976) Mechanical tunnelling, progress and expectations, Tunnelling '76, IMM, Jones, M.J. (Ed.):11-20

[14] Graham PC (1976) Rock exploration for machine 
manufacturers. In: Bieniawski, Z. T. (Ed.), Exploration for Rock Engineering. Balkema, Johannesburg:173-180

[15] Farmer IW, Glossop NH (1980) Mechanics of disc cutter penetration. Tunnels Tunnelling. Int. 12 (6):22-25

[16] Snowdon RA, Ryley MD, Temporal J, Crabb GI (1983) October. The effect of hydraulic stiffness on tunnel boring machine performance, International Journal of Rock Mechanics and Mining Sciences \& Geomechanics Abstracts,20(5):203-214

[17] Büchi E (1984) Einflussgeologischer Parameter auf die Vortriebsleistungeiner Tunnel bohrmaschine. Inaugural dissertation, Philosophisch-naturwissenschaftliche Fakultät, Universität Bern, $p$ 136

[18] Morimoto T, Hori M (1986) Performance characteristics of a tunnel boring machine from the geomechanical viewpoint. In International Journal of Rock Mechanics and Mining Sciences \& Geomechanics Abstracts, 23(1):55-66

[19] Hughes HM (1986) The relative cuttability of coal measures rock. Min. Sci. Technol. 3:95-109

[20] Rostami, J. and Ozdemir, L., 1993, May. Computer modeling for cutterhead design and layout of mechanical excavators. In Proc. of Institute of Shaft Drilling Technology (ISDT) annual technical meeting (pp. 2-6).

[21] Nilsen B, Ozdemir L (1993) Hard rock tunnel boring prediction and field performance. International Proceedings of the Rapid Excavation and Tunneling Conference, Society for Mining, Metallurgy \& Exploration, Inc.:833-833

[22] Rostami J, Ozdemir L, Nilson B (1996) Comparison between CSM and NTH hard rock TBM performance prediction models. In Proceedings of Annual Technical Meeting of the Institute of Shaft Drilling Technology, Las Vegas:1-10

[23] Bruland A (1998) Hard rock tunnel boring. Doctoral dissertation, 1-10 Volumes, Norwegian University of Science and Technology (NTNU), Trondheim, Norway

[24] Barton N (1999) TBM performance estimation in rock using QTBM. Tunnels and Tunnelling International:30-34

[25] Boniface A (2000) Tunnel boring machine performance in basalts of the Lesotho formation. Tunnelling and Underground Space Technology, 15(1):49-54
[26] Barton N (2000) TBM Tunneling in Jointed and Faulted Rock. Balkema, Brookfield, p 9

[27] Cigla M, Yagiz S, Ozdemir L (2001) Application of tunnel boring machines in underground mine development. In: 17th international mining congress and exhibition of Turkey:155-164.

[28] Kahraman S (2002) Correlation of TBM and drilling machine performances with rock brittleness. Engineering Geology, 65(4):269-283.

[29] Sapigni M, Berti M, Bethaz E, Busillo A, Cardone G (2002) TBM performance estimation using rock mass classifications. International Journal of Rock Mechanics and Mining Sciences, 39(6):771-788

[30] Benardos AG, Kaliampakos DC (2004) Modelling TBM performance with artificial neural networks. Tunnelling and Underground Space Technology, 19(6):597-605

[31] Bilgin N, Feridunoglu C, Tumac D, Cinar M, Palakci Y, Gunduz O, Ozyol L (2005) May. The performance of a full-face tunnel boring machine (TBM) in Tarabya (Istanbul). In Proceedings, 31st ITA-AITES World Tunnel Congress:821-826

[32] Gong QM, Jiao YY, Zhao J (2006) Numerical modelling of the effects of joint spacing on rock fragmentation by TBM cutters. Tunnelling and Underground Space Technology, 21(1):46-55

[33] Von Preinl ZT, Tamames BC, Fernandez JM, Hernandez MA (2006) Rock masse excavability indicator: new way to selecting the optimum tunnel construction method. Tunnelling and Underground Space Technology. 21 (3-4), p 237

[34] Yagiz S, Gokceoglu C, Sezer E, Iplikci S (2009) Application of two non-linear prediction tools to the estimation of tunnel boring machine performance. Engineering Applications of Artificial Intelligence, 22(4):808-814

[35] Hassanpour J, Rostami J, Khamehchiyan M, Bruland A, Tavakoli HR (2010) TBM performance analysis in pyroclastic rocks: a case history of Karaj water conveyance tunnel. Rock Mechanics and Rock Engineering, 43(4):427-445

[36] Gong QM, Zhao J (2009) Development of a rock mass characteristics model for TBM penetration rate prediction. Int. J. Rock Mech. Min. Sci. 46(1):818

[37] Gholamnejad J, Tayarani N (2010) Application of artificial neural networks to the prediction of tunnel boring machine penetration rate. Mining Sci. Technol. (China) 20(5):727-733 
[38] Hamidi JK, Shahriar K, Rezai B, Rostami J (2010) Performance prediction of hard rock TBM using Rock Mass Rating (RMR) system. Tunnel. Underground Space Technol. 25(4):333-345

[39] Benato A, Oreste P (2015) Prediction of penetration per revolution in TBM tunneling as a function of intact rock and rock mass characteristics. Int. J. Rock Mech. Min. Sci. 74:119-127

[40] Salimi A, Rostami J, Moormann C, Delisio A (2016) Application of non-linear regression analysis and artificial intelligence algorithms for performance prediction of hard rock TBMs. Tunnelling and Underground Space Technology, 58:236-246

[41] Liu Q, Liu J, Pan Y, Kong X, Hong K (2017) A case study of TBM performance prediction using a Chinese rock mass classification systemHydropower Classification $(\mathrm{HC})$ method. Tunnelling and Underground Space Technology, 65:140-154.

[42] Namli M, Bilgin N (2017) A model to predict daily advance rates of EPB-TBMs in a complex geology in Istanbul. Tunnelling and Underground Space Technology, 62:43-52

[43] Liu B, Wang R, Guan Z, Li J, Xu Z, Guo X, Wang Y (2019) Improved support vector regression models for predicting rock mass parameters using tunnel boring machine driving data. Tunnelling and Underground Space Technology, 91, p.102958.

[44] Wallis S (1999) Record setting TBMs on China's long Yellow River drives. Tunnel, 1:19-26.

[45] Barla G, Pelizza S (2000) TBM tunnelling in difficult ground conditions. In ISRM International Symposium. International Society for Rock Mechanics and Rock Engineering, p 20

[46] Wanner H, Aeberli U (1979) Tunnelling machine performance in jointed rock. In 4th ISRM Congress. International Society for Rock Mechanics and Rock Engineering, $\mathrm{p} 8$

[47] Johannessen $\mathrm{O}$, Jacobsen K, Ronn PE, Moe HL (1995) Tunnelling costs for drill and blast. Project Report 2C-95, Unit-NTH, Department of Building and Construction Engineering.

[48] Salimi A, Rostami J, Moormann C (2017) Evaluating the suitability of existing rock mass classification systems for TBM performance prediction by using a regression tree. Procedia Engineering, 191:299-309

[49] Stack B (1995) Encyclopaedia of Tunnelling, Mining, and Drilling Equipment. Muden Publishing Company, $743 p$
[50] Yin L, Miao C, He G, Dai F, Gong Q (2016) Study on the influence of joint spacing on rock fragmentation under TBM cutter by linear cutting test. Tunnelling and Underground Space Technology, 57:137-144

[51] Howarth DF (1981) The effect of jointed and fissured rock on the performance of tunnel boring machines. In: Proceeding of the International symposium on weak rock. Tokyo, Japan:10691074.

[52] Hassanpour J, Rostami J, Zhao J (2011) A new hard rock TBM performance prediction model for project planning. Tunnelling and Underground Space Technology, 26(5):595-603

[53] Bell FG (1980) Engineering Geology and Geotechnics, Newnes-Butterworth, London:171172

[54] Paltrinieri E, Sandrone F, Zhao J (2016) Analysis and estimation of gripper TBM performances in highly fractured and faulted rocks. Tunnelling and Underground Space Technology, 52:44-61

[55] Grandori R, Jaeges M, Antoini F, Vigl L (1995) Evinos-Mornos Tunnel, Greece construction of a 30 $\mathrm{km}$ long hydraulic tunnel in less than three year under the most adverse geological condition. In: Proceeding of the francisco, USA:7747-7767

[56] Barton N (2003) Fault zones and TBM. Geotechnical Risk in Rock Tunnels: Selected Papers from a Course on Geotechnical Risk in Rock Tunnels, Aveiro, Portugal, 16-17 April 2004, p 75

[57] Dammyr (2017) Pressurized TBM-shield tunneling under the subsidence sensitive grounds of Oslo: possibilities and limitations. Tunnelling and Underground Space Technology, 66:47-55

[58] Hoek E, Marinos P, Bennissi M (1998) Applicability of the Geological Strength Index (GSI) classification for the very weak and sheared rock masses. The case of the Athens schist formation. Bull. Eng. Geol. Environ. 57:151-160

[59] Hassanpour J, Esmaeili Vardanjani S, Cheshomi A, Rostami J, (2019) Engineering geological studies used for redesigning and employing a hard rock TBM in soft rock formations of Chamshir water conveyance tunnel. Geopersia, 9(1):1-20

[60] Mostafaei M, Far AHR, Rastegarnia A (2019) Assessment of the impact of case parameters affecting abrasion and brittleness factors in alluviums of line 2 of the Tabriz subway, Iran. 
Bulletin of Engineering Geology and the Environment, 78(5):3851-3861

[61] Cassinelli F, Cina S, Innaurato N, Mancini R, Sampaolo A (1982) Power consumption and metal wear in tunnel-boring machines: analysis of tunnelboring operation in hard rock. Tunnelling ' 82 , London. Inst. Min. Metall.:73-81

[62] Nelson P, O'Rourke TD, Kulhawy FH (1983) January. Factors affecting TBM penetration rates in sedimentary rocks. In The 24th US Symposium on Rock Mechanics (USRMS). American Rock Mechanics Association, p 12

[63] Boyd RJ (1986) Hard rock continuous mining machine: Mobile Miner MM-120. In Rock excavation engineering seminar. Dept. Mining and Met. Eng, University of Queensland.

[64] Innaurato N, Mancini R, Rondena E, Zaninetti A (1991) Forecasting and effective TBM performances in a rapid excavation of a tunnel in Italy. In: Proceedings of the Seventh International Congress ISRM, Aachen: 1009-1014.

[65] Ramezanzadeh A, Rostami J, Tadic D (2008) Impact of rock mass characteristics on hard rock tunnel boring machine performance. 13th International Australian Tunnelling Conference, Melbourne, Australia:213-220
[66] Ribacchi R, Lembo-Fazio A (2005) Influence of rock mass parameters on the performance of a TBM in a gneissic formation (Varzo Tunnel). Rock Mech. Rock Eng. 38 (2):105-127

[67] Mahdevari S, Shahriar K, Yagiz S, Shirazi MA (2014) A support vector regression model for predicting tunnel boring machine penetration rates. International Journal of Rock Mechanics and Mining Sciences, 72:214-229.

[68] Bieniawski ZT, Grandori R (2007) Predicting TBM excavability - part II. Tunnels \& Tunnelling International: $15-18$

[69] Deshmukh, S., Raina, A.K., Pandey, P., Vajre, R., Trivedi, R. and Murthy, V.M.S.R., 2019. Mechanical wear of cutters in tunnel boring machines-a comprehensive review. Journal of Mines, Metals \& Fuels, 67(9), pp.391-402.

[70] Ellecosta P, Käsling H, Thuro K (2019) Wear phenomena in tunnel boring machine (TBM), hard rock drilling-reasons and consequences. In IAEG/AEG Annual Meeting Proceedings, San Francisco, California, 2018, 4:57-64

[71] Zhang Q, Liu Z, Tan J (2019) Prediction of geological conditions for a tunnel boring machine using big operational data. Automation in Construction, 100:73-83 


\title{
UTICAJ GEOLOGIJE NA UČINAK MAŠINE ZA PROBIJANJE TUNELA - PREGLED
}

\author{
P.K. Pandey ${ }^{1}$, A.K. Raina1\#, S. Deshmukh¹, R. Trivedi', R. Vajre', V.M.S.R. Murthy²
}

${ }^{1}$ CSIR-Central Institute of Mining and Fuel Research, Nagpur Research Centre, Nagpur, India

${ }^{2}$ Department of Mining Engineering, IIT(ISM), Dhanbad, India

(Primljen: 21. novembar 2019.; Prihvaćen: 8. maj 2020.)

\section{Izvod}

Mašine za probijanje tunela se koriste za iskopavanje raznih vrsta tla i stena za tunele sa kružnim presekom. Nekoliko objavljenih studija se bavilo ispitivanjem uloge stenske mase u određivanju brzine iskopavanja i napredovanja mašine za probijanje tunela. Izvršen je sveobuhvatni pregled literature kako bi se odredio uticaj geoloških uslova na učinak mašine za probijanje tunela prilikom kojeg je utvrđeno da se različite karakteristike stena koriste za utvrđivanje učinka ove mašine. Napredak mašine za probijanje tunela je povezan sa inherentnim osobinama stenske mase, nepromenljivim osobinama stena, kao i sa okolnim geološkim uslovima. Nekoliko autora je utvrdilo da ekstremni geološki uslovi imaju veliki uticaj na napredak mašine. Pregledom literature je takođe utvrđeno da raspored pukotina, ugao između slabe ravni i ose tunela, kvalitet stene i broj pukotina predstavljaju najvažnije parametre koji utiču na brzinu napredovanja mašine za probijanje tunela. Najmanje 12 varijabli nedirnutih stena je korišćeno za određivanje učinka mašine za probijanje tunela, gde je kombinovano od jedne do sedam ovih varijabli. Utvrđeno je da čvrstoća na pritisak, čvrstoća na istezanje $i$ indeks krtosti predstavljaju najvažnije osobine za ispitivanje. Različiti autori su koristili klasifikaciju stenske mase ili indeks učinka mašine za probijanje tunela za predviđanje učinka mašine, a isto tako i za definisanje metodologije odabira. Upotreba dinamičkih osobina stene/stenske mase je identifikovana kao siva zona za buduća istraživanja.

Ključne reči: Učinak mašine za probijanje tunela; Osobine stenske mase; Nepromenljive osobine stena; Posebni uslovi; Pregled. 